\title{
POTASSIUM MONITORING IN HEART FAILURE PATIENTS RECEIVING COMBINED THERAPY OF CAPTOPRIL AND FUROSEMIDE
}

\author{
Hubby $^{1}$, Suharjono $^{2}$, Zaenab Djafar ${ }^{3}$ \\ ${ }^{1}$ Master of Clinical Pharmacy, Faculty of Pharmacy, Universitas Airlangga \\ ${ }^{2}$ Department of Clinical Pharmacy, Faculty of Pharmacy, Universitas Airlangga \\ ${ }^{3}$ Department of Cardiology and Vascular Medicine, Dr. Wahidin Sudirohusodo Hospital, Makassar
}

\begin{abstract}
ABSTRAK
Pada penatalaksanaan gagal jantung direkomendasikan penggunaan kombinasi ACEi (Kaptopril) dengan Diuretik (Furosemid), ACEi mempunyai efek samping hiperkalemia 10-38\% pada pasien rawat inap dan 10\% pada pasien rawat jalan, lebih meningkat pada pasien gagal ginjal dan Diabetes Mellitus, pada penggunaan diuretik terjadi hipokalemia 5-20\% pada pasien rawat jalan. Hiperkalemia dan hipokalemia keduanya harus dihindari pada pasien gagal jantung, karena dapat menyebabkan terjadinya gangguan konduksi pada jantung seperti aritmia jantung Penelitian ini bertujuan memantau kadar kalium pada penggunaan kombinasi terapi Kaptopril dengan Furosemid pada pasien gagal jantung. Penelitian dilakukan menggunakan metode Observasional Analisis Cross Sectional Prospektif, dilakukan bulan Januari-Mei 2015 pada pasien gagal jantung pria dan wanita NYHA II-III yang mendapat kombinasi terapi Kaptopril dengan Furosemid yang memenuhi kriteria inklusi yang dirawat di ruang CVCU RSUP Dr. Wahidin Sudirohusodo Makassar. Kadar Kalium pasien diukur pre dan post pemberian kombinasi terapi. Sebanyak 37 pasien yang memenuhi kriteria inklusi dan eksklusi pada penelitian ini, 31 pasien pria (83,8\%) dan 6 pasien wanita (16,2\%) usia antara 35-80 tahun, selama penelitian ini sesudah pemberian kombinasi terapi, 5 pasien $(13,5 \%)$ mengalami hipokalemia $(<3,5 \mathrm{mmol} / \mathrm{L})$ dan 2 pasien (5,4\%) mengalami hiperkalemia (>5 mmol/L) serta sebanyak 30 pasien $(81,1 \%)$ kadar kalium normal (3,5-5,0 mmol/L). Hasil uji paired t test $p=0,432$ ( $p>$ ?; ?=0,05) menunjukkan tidak terdapat perbedaan bermakna antara kadar kalium pre dan kadar kalium post. Sebagai simpulan, penggunaan kombinasi terapi Kaptopril dan Furosemid, risiko hiperkalemia dan hipokalemia tidak bermakna tetapi perlu dimonitoring kadar kalium dan EKG pasien. (FMI 2016;52:285-289)
\end{abstract}

Kata kunci: gagal jantung, kombinasi terapi kaptopril dengan furosemid, hiperkalemia, hipokalemia, acei, diuretik.

\begin{abstract}
In the treatment of heart failure is recommended the use of a combination of ACEI (captopril) with diuretics (furosemide), ACEI has the side effect of hyperkalemia 10-38\% in hospitalized patients and 10\% in outpatients, is increased in patients with renal failure and diabetes mellitus, the use diuretics occur hypokalemia 5-20\% in outpatients. Hyperkalemia and hypokalemia both should be avoided in heart failure patients, because it can cause cardiac conduction disorders such as cardiac arrhythmias This study aims to monitor levels of potassium in the use of combination therapy with furosemide captopril in heart failure patients. The study was conducted using the method Prospective Observational Cross Sectional Analysis, conducted in January-May 2015 in heart failure patients male and female NYHA II-III receiving combination therapy with furosemide Captopril met the inclusion criteria were treated in the department CVCU Dr. Wahidin Sudirohusodo Makassar. Potassium levels were measured pre and post administration of the combination therapy. A total of 37 patients met the inclusion and exclusion criteria in this study, 31 male patients (83.8\%) and 6 female patients (16.2\%) aged between 35-80 years, during this study after administration of the combination therapy, 5 patients ( $13.5 \%)$ had hypokalemia $(<3.5 \mathrm{mmol} / \mathrm{L})$ and 2 patients $(5.4 \%)$ experienced hyperkalemia $(>5 \mathrm{mmol} / \mathrm{L})$ and 30 patients $(81.1 \%)$ of normal potassium levels (3, 5 to $5.0 \mathrm{mmol} / \mathrm{L})$. The test results paired t test $p=0.432(p>? ; ?=0.05)$ showed no significant differences between potassium levels pre and post potassium levels. In conclusion, the use of a combination of captopril and furosemide therapy, the risk of hyperkalemia and hypokalemia not significant but need to be monitored levels of potassium and ECG patient. (FMI 2016;52:285-289)
\end{abstract}

Keywords: heart failure, a combination of captopril therapy with furosemide, hyperkalemia, hypokalemia, ACEI, diuretic.

Correspondence: Department of Clinical Pharmacy, Faculty of Pharmacy, Universitas Airlangga, Jalan Dharmawangsa Dalam Selatan, Surabaya, Indonesia.

\section{INTRODUCTION}

Heart failure or heart failure is a complex clinical syndrome, which is characterized by the inability of the heart to pump blood throughout the body adequately, due to structural and functional disturbances of the heart (Panggabean 2014). Heart failure is a major problem for a growing number, frequency of re-hospitalization and death. The cause of the increase is the successful handling of myocardial infarction, increasing the number of 
people who reach old age and they often found risk factors such as hypertension, anemia, diabetes mellitus (DM), smoking and obesity (McMurray 2012).

Treatment of heart failure based on the pathophysiology of which is to increase $\mathrm{CO}$ by reducing afterload/ preload and increase cardiac contractility and prevent the remodeling of the overall target of therapy is to reduce symptoms, improve quality of life, slow disease progression, reduce morbidity and prolong life expectancy (Harvey 2009). The concept of pharmacological treatment of heart failure with diuretics if there is fluid retention and volume overload occurs when, Angiotensin Converting Enzyme inhibitors (ACEI) or Angiotensin Receptor Blocker (ARB) as antiremodelling and administration of $\beta$-blockers or digitalis to increase contractility (Yancy 2013).

Increased flow of $\mathrm{Na}+$ and water causes increased excretion of potassium, the total effect of inhibition kotransporter lead chloride, sodium, potassium and $\mathrm{H}+$ ions remain in the lumen thus help tereksresi that cause electrolyte disturbances such as hypokalemia, hypokalemia in use diuertik about $5-20 \%$ of patients outpatient (Dursun 2006, Lim 2013). The use of ACEI inhibit the formation of angiotensin I (Ang I) into angiotensin II (Ang II), as the activation of the SRAA, Ang II is a potent vasoconstrictor and stimulates the secretion of aldosterone and increased vascular resistance (afterload), Ang II also causes cell growth myocytes, hypertrophy and remodeling of the heart muscle, ACEI use inhibit the production of Ang II, thereby decreasing peripheral vascular resistance (afterload) and prevent sodium and water retention via aldosterone effects and increase bradykinin. Bradykinin stimulate the formation of nitrogen monoxide (NO) and prostaglandin that serves as antimitotic and antiremodelling (Lim 2013), side effects of ACEI use hyperkalemia occurred around $10-38 \%$ in hospitalized patients, $10 \%$ in outpatients and more risk is increased in patients failing kidney and DM (Felker 2011).

Treatment of heart failure recommended the use of a combination of a diuretic and ACEI, according to the guidelines of the American College of Cardiology Foundation/American Heart Association (ACCF/AHA) in 2013 on the management of heart failure in combination with ACEI use of diuretics. The combination of both needs, diuretics reduce the burden of excess fluid (preload), pulmonary congestion and peripheral edema normally found in heart failure, while ACEI decrease afterload and heart remodeling (McMurray 2012). The use of ACEI in the treatment of heart failure can cause hyperkalemia, whereas diuretics may occur hypokalemia, the use of combination therapies of captopril and furosemide for heart failure patients need to be monitored electrolyte patients, particularly potassium, due to hyperkalemia and hypokalemia both should be avoided in heart failure patients, can cause cardiac conduction disorders such as cardiac arrhythmia (Felker 2011).

This research will be monitoring levels of potassium in the use of a combination of captopril and furosemide therapy to patients with heart failure treated in Cardio vascular Care Unit (CVCU) Hospital Dr. Wahidin Sudirohusodo Makassar, it is necessary in order to achieve an effective treatment.

\section{MATERIALS AND METHODS}

The study was conducted using the method Prospective Observational Cross Sectional Analysis. The samples used were 37 patients. The study was conducted at room CVCU Hospital. Dr. Wahidin Sudirohusodo Makassar. Sampling was conducted from January to May 2015. The samples taken are met inclusion criteria and get rid of the exclusion. After signing the informed consent will be monitoring during therapy and blood sampling performed on samples of research and examination potassium level is performed in the Laboratory of Hospital Dr. Wahidin Sudirohusodo Makassar.

\section{RESULTS}

In Table 1 shows the demographic data of patients who serve as research samples, including, gender, age, diagnosis, potassium levels after therapy and the type of combination therapy given.

Table 1. Demographic data patients included in the inclusion criteria

\begin{tabular}{|c|c|c|c|}
\hline $\begin{array}{c}\text { Patient's } \\
\text { characteristics }\end{array}$ & & $\begin{array}{c}\text { Total } \\
\text { patients }\end{array}$ & $\%$ \\
\hline \multirow{2}{*}{ Sex } & Male & 31 & $83.8 \%$ \\
\hline & Female & 6 & $16.2 \%$ \\
\hline \multirow{3}{*}{ Age } & 35 - 50 years & 11 & $29.7 \%$ \\
\hline & $51-65$ years & 18 & $48.7 \%$ \\
\hline & 66 - 80 years & 8 & $21.6 \%$ \\
\hline \multirow{2}{*}{ Diagnosis } & NYHA - II & 31 & $83.8 \%$ \\
\hline & NYHA - III & 6 & $16.2 \%$ \\
\hline $\begin{array}{l}\text { Potassium } \\
\text { level pre- } \\
\text { therapy }\end{array}$ & $\begin{array}{l}\text { Normal }(3.5-5.0 \\
\text { mmol) }\end{array}$ & 37 & $100 \%$ \\
\hline \multirow{4}{*}{$\begin{array}{l}\text { Potassium } \\
\text { level post- } \\
\text { therapy }\end{array}$} & Hypokalemia & & \\
\hline & $\begin{array}{l}<3.5 \mathrm{mmol} \\
\text { Normokalemia }\end{array}$ & $\begin{array}{c}5 \\
30\end{array}$ & $\begin{array}{l}13.5 \% \\
81.1 \%\end{array}$ \\
\hline & $3.5-5.0 \mathrm{mmol}$ & 2 & $5.4 \%$ \\
\hline & Hyperkalemia & & \\
\hline
\end{tabular}




\begin{tabular}{|c|c|c|c|}
\hline & $>5 \mathrm{mmol}$ & & \\
\hline $\begin{array}{l}\text { Combined } \\
\text { therapy } \\
\text { Captopril + } \\
\text { Furosemide }\end{array}$ & $\begin{array}{l}\text { Captopril } 6.25+ \\
\text { Furosemide } 40 \\
\text { Captopril } 12.5+ \\
\text { Furosemide } 40 \\
\text { Captopril } 12.5+ \\
\text { Furosemide } 80 \\
\text { Captopril } 25+ \\
\text { Furosemide } 40 \\
\text { Captopril } 25+ \\
\text { Furosemide } 80\end{array}$ & $\begin{array}{c}6 \\
9 \\
16 \\
3 \\
3\end{array}$ & $\begin{array}{l}16.2 \% \\
24.3 \% \\
43.3 \% \\
8.1 \% \\
8.1 \%\end{array}$ \\
\hline
\end{tabular}

The dose in this study there is no intervention either on captopril and furosemide therapy, dose adjusted to the patient's condition. Captopril tablets given orally at a dose strengths of $6.25 \mathrm{mg}, 12.5 \mathrm{mg}$ and $25 \mathrm{mg} 3$ times daily administration. Captopril given small doses ranging from $6.25 \mathrm{mg}$ can be titrated up to a maximum dose, given three times a day.

Furosemide given in this study through iv in dosage form of $10 \mathrm{mg} / \mathrm{ml}$ in ampoules $2 \mathrm{ml}$, administration of furosemide iv starting dose of $40 \mathrm{mg}$ a day may be increased, doses every 8 hours or 12 hours, through the provision of syringe pump or bolus and intermittent until a stable condition and continued with oral furosemide $40 \mathrm{mg} 1 \mathrm{x}$. Patients who received the combination therapy of $6.25 \mathrm{mg}$ captopril and furosemide 40 $\mathrm{mg}$ as 6 patients (16.2\%), captopril $12.5 \mathrm{mg}$ and $40 \mathrm{mg}$ of furosemide were 9 patients $(24.3 \%)$, captopril and furosemide $12.5 \mathrm{mg} 80 \mathrm{mg}$ of 16 patients (43.3\%), captopril $25 \mathrm{mg}$ and furosemide $40 \mathrm{mg}$ as many as three patients $(8.1 \%)$ and captopril $25 \mathrm{mg}$ and furosemide 80 $\mathrm{mg}$ as many as three patients $(8.1 \%)$. A total of 37 patients in this study before getting combination therapy normal potassium levels $(3,5-5.0 \mathrm{mmol} / \mathrm{L})(\mathrm{K} 0)$.

Table 2. Summary of potassium levels after administration of therapy

\begin{tabular}{|c|c|c|c|c|c|}
\hline No & $\begin{array}{l}\text { Combined } \\
\text { therapy }\end{array}$ & $\begin{array}{c}\text { Total } \\
\text { patients }\end{array}$ & $\begin{array}{c}\text { Hypokalemia } \\
<3.5 \\
\text { mmol/L } \\
\text { (patients) }\end{array}$ & $\begin{array}{c}\text { Normokale } \\
\text { mia } \\
3.5-5.0 \\
\text { mmol/L } \\
\text { (patients) }\end{array}$ & $\begin{array}{c}\text { Hiperkale } \\
\text { mia }>5.0 \\
\text { mmol/L } \\
\text { (patients) }\end{array}$ \\
\hline 1 & $\begin{array}{l}\text { Captopril } \\
6.25 \mathrm{mg} \\
\text { peroral+Fu } \\
\text { rosemide } \\
40 \mathrm{mg} \text { iv }\end{array}$ & 6 & - & 6 & - \\
\hline 2 & $\begin{array}{l}\text { Captopril } \\
12.5 \mathrm{mg} \\
\text { peroral+ } \\
\text { Furosemid } \\
\text { e } 40 \mathrm{mg} \text { iv }\end{array}$ & 9 & 3 & 5 & 1 \\
\hline 3 & $\begin{array}{l}\text { Captopril } \\
12.5 \mathrm{mg} \\
\text { peroral+ } \\
\text { Furosemid } \\
\text { e } 80 \mathrm{mg} \text { iv }\end{array}$ & 16 & 2 & 13 & 1 \\
\hline 5 & $\begin{array}{l}\text { Captopril } \\
25 \mathrm{mg} \\
\text { peroral+ } \\
\text { Furosemid } \\
\text { e } 40 \mathrm{mg} \text { iv }\end{array}$ & 3 & - & 3 & - \\
\hline
\end{tabular}

\begin{tabular}{|c|c|c|c|c|c|}
\hline 6 & $\begin{array}{l}\text { Captopril } \\
25 \mathrm{mg} \\
\text { peroral+ } \\
\text { Furosemid } \\
\text { e } 80 \mathrm{mg} \text { iv }\end{array}$ & 3 & - & 3 & - \\
\hline
\end{tabular}

Table 3. Average levels of potassium in the combination of captopril and furosemide

\begin{tabular}{|c|c|c|c|c|}
\hline No & Types & $\begin{array}{c}\mathrm{K}^{+} \text {level } \\
\text { pre- } \\
\text { therapy } \\
(\mathrm{mmol} / \mathrm{L})\end{array}$ & $\begin{array}{l}\mathrm{K}^{+} \text {level } \\
\text { post- } \\
\text { therapy } \\
(\mathrm{mmol} / \mathrm{L})\end{array}$ & $\begin{array}{l}\text { Mean and } \\
\text { Range } \\
(\mathrm{mmol})\end{array}$ \\
\hline \multirow[t]{6}{*}{1} & \multirow{6}{*}{$\begin{array}{l}\text { Captopril } 6.25 \mathrm{mg} \\
\text { per oral }+ \\
\text { Furosemide } 40 \mathrm{mg} \\
\text { iv }\end{array}$} & 4.1 & 3.8 & \multirow{6}{*}{$\begin{array}{l}\text { Mean : } \\
4.10 \pm 0.4289 \\
\text { Range : } \\
3.7-4.8\end{array}$} \\
\hline & & 4.3 & 4.4 & \\
\hline & & 3.5 & 3.8 & \\
\hline & & 3.9 & 4.1 & \\
\hline & & 3.6 & 3.7 & \\
\hline & & 4.5 & 4.8 & \\
\hline \multirow[t]{9}{*}{2} & \multirow{9}{*}{$\begin{array}{l}\text { Captopril } 12.5 \mathrm{mg} \\
\text { peroral }+ \\
\text { Furosemide } 40 \mathrm{mg} \\
\text { iv }\end{array}$} & 4.7 & 3.8 & \multirow{9}{*}{$\begin{array}{l}\text { Mean : } \\
3.77 \pm 0.6364 \\
\text { Range : } \\
2.9-5.1\end{array}$} \\
\hline & & 3.9 & 3.2 & \\
\hline & & 4.2 & 2.9 & \\
\hline & & 3.7 & 5.1 & \\
\hline & & 3.5 & 3.3 & \\
\hline & & 3.7 & 3.8 & \\
\hline & & 4.0 & 4.1 & \\
\hline & & 3.6 & 3.7 & \\
\hline & & 4.4 & 4.0 & \\
\hline \multirow[t]{16}{*}{3} & \multirow{16}{*}{$\begin{array}{l}\text { Captopril } 12.5 \mathrm{mg} \\
\text { peroral + } \\
\text { Furosemide } 80 \mathrm{mg} \\
\text { iv }\end{array}$} & 4.4 & 3.4 & \multirow{16}{*}{$\begin{array}{l}\text { Mean : } \\
3.95 \pm 0.5164 \\
\text { Range : } \\
3.2-5.1\end{array}$} \\
\hline & & 4.0 & 3.2 & \\
\hline & & 3.5 & 3.7 & \\
\hline & & 3.5 & 3.5 & \\
\hline & & 4.3 & 4.5 & \\
\hline & & 5.0 & 3.7 & \\
\hline & & 4.2 & 4.0 & \\
\hline & & 3.9 & 3.5 & \\
\hline & & 4.7 & 5.1 & \\
\hline & & 3.5 & 3.6 & \\
\hline & & 3.5 & 3.6 & \\
\hline & & 5.0 & 4.5 & \\
\hline & & 4.6 & 4.5 & \\
\hline & & 4.6 & 4.2 & \\
\hline & & 3.8 & 4.0 & \\
\hline & & 3.9 & 4.2 & \\
\hline \multirow[t]{3}{*}{4} & \multirow{3}{*}{$\begin{array}{l}\text { Captopril } 25 \mathrm{mg} \\
\text { peroral + } \\
\text { Furosemide } 40 \mathrm{mg} \\
\text { iv }\end{array}$} & 3.9 & 3.9 & Mean : \\
\hline & & 4.4 & 4.8 & $4.2 \pm 0.5196$ \\
\hline & & 3.5 & 3.9 & $\begin{array}{l}\text { Range : } \\
3.9-4.8\end{array}$ \\
\hline \multirow[t]{3}{*}{5} & \multirow{3}{*}{$\begin{array}{l}\text { Captopril } 25 \mathrm{mg} \\
\text { peroral + } \\
\text { Furosemide } 80 \mathrm{mg} \\
\text { iv }\end{array}$} & 3.5 & 3.7 & Mean : \\
\hline & & 3.5 & 4.1 & $4.1+0.4000$ \\
\hline & & 4.4 & 4.5 & $\begin{array}{l}\text { Range : } \\
3.7-4.5\end{array}$ \\
\hline
\end{tabular}

Observations potassium levels before and after administration of furosemide and captopril combination therapy can be seen in Table 4 that have been processed statistically

Table 4. Results of statistical analysis of potassium levels of heart failure patients before and after treatment captopril and furosemide

\begin{tabular}{|c|c|c|c|c|c|}
\hline \multirow[b]{2}{*}{ Variables } & \multicolumn{2}{|c|}{ Difference } & \multirow[b]{2}{*}{$\mathrm{t}_{\text {count }}$} & \multirow[b]{2}{*}{ Df } & \multirow{2}{*}{$\begin{array}{l}\text { Sig (2- } \\
\text { tailed) }\end{array}$} \\
\hline & Mean & $\mathrm{Sd}$ & & & \\
\hline $\begin{array}{l}\text { Potassium level } \\
\text { pre-Potassium } \\
\text { level post }\end{array}$ & 0.0703 & 0.5374 & 0.795 & 36 & 0.432 \\
\hline
\end{tabular}


Table 4 shows that the differences in serum potassium test results before and after therapy. The test results indicate normality using the Kolmogorov-Smirnov potassium levels pre and post treatment data were normally distributed. Pre potassium $\mathrm{p}$ value $=0.595$ and p potassium post $=0.771(\mathrm{p}>? ; ?=0.05)$. The test results paired $\mathrm{t}$ test $\mathrm{p}=0.432(\mathrm{p}>? ; ?=0.05)$ showed no significant differences between potassium levels pre and post potassium levels.

\section{DISCUSSION}

This study was conducted to monitor potassium levels in heart failure patients after administration of the combination therapy of captopril and furosemide, the parameters used in patients that levels of electrolytes, especially potassium levels in patients, serum urea and creatinine. In the study sample as many as 37 patients, there was no intervention on the dose and route of administration depending on the patient's condition while being treated by the clinician. Patients in this study were patients with heart failure NYHA II-III were treated at CVCU day care during started 4 days.

Administration of drugs in the room CVCU usually in the form of iv with intermittent or bolus administration to get the effect more quickly, and be able to use a syringe pump to get a fixed dose and continuous and can be stopped if it is not needed. Giving oral form is given if the condition is stable and there is only preparation in tablet form.

Handling of patients with heart failure by reducing afterload, through the use of ACEI by inhibiting the formation of Ang II from Ang I, Ang II is a powerful vasokontriktor, stimulates the secretion of aldosterone and other vasopressin (Lim 2013). Inhibition of Ang II is the foundation of therapy for heart failure, according to the ACCF/AHA 2013 Award ACEI is recommended for all patients with heart failure to reduce mortality and morbidity (grade Ia), unless there are contra-indications, ACEI inhibit the formation of Ang II and degradation Bradikinin and stimulates synthesis vasodilating substances including PEG and NO. ACEI effectively prevent left ventricular hypertrophy by reducing direct stimulation of Ang II also cause remodeling (Hunt, 2004, Yancy 2013).

ACEI usually started on a low dose, as anti remodeling of the heart and can then be titrated up within a few weeks up to a maximum dose that can be tolerated. However, if there are limitations in increasing doses because of side effects, the low doses can still provide considerable advantages for both mortality and improvement of symptoms of heart failure (Yancy
2013), the side effects that can be caused to the use of ACEI occurrence of hyperkalemia in hospitalized patients $10-38 \%$, the $10 \%$ of outpatients and coughing 3-15\% (Felker 2011).

Captopril is an ACEI group sulfhydril not prodrug, a short-acting has a direct effect on the heart in terms of preventing remodeling and expansion inhibit myocardial damage, treatment is initiated from the 3 times daily dose of $6.25 \mathrm{mg}$ per day may be increased (Kabo 2010). The mechanism of hyperkalemia in the use of ACEI, where ACEI inhibit the formation of Ang II, so that prisoners peripheral vascular decreased (afterload) and prevent sodium and water retention through the effects of aldosterone by the mechanism of sodium reabsorbed in the distal tubule and duct kolektus in exchange for $\mathrm{K}+$ with $\mathrm{H}+$ through the canal sodium aldosteronesensitive potassium secreted later, the inhibition of ang II by ACEI will also inhibit potassium secretion of aldosterone thus also decreases will lead to hyperkalemia (McMurray 2012).

According to the CCS heart failure management guidelines (Canadian Cardiovascular Society 2012) recommends iv diuretics as first-line therapy in patients with heart failure, CCS recommends the use of furosemide in patients requiring iv diuretics, either intermittent doses (2-3 times daily) or intravenous continuously. Furosemide is a sulfonamide-derived class, the initial dose of furosemide administration is 20-40 mg daily doses of 40-240 mg for treatment of heart failure (McMurray 2012).

In this study, patients received furosemide in intermittent 2 x $20 \mathrm{mg}$ and 2 x $40 \mathrm{mg}$ iv was a continuous infusion using a syringe pump rate of 10 $\mathrm{mg}$ /hour for 8 hours, in case of hypokalemia on the use of furosemide, it can be stopped, or in combination with a potassium-sparing diuretic such as spironolactone and if hypotension use of furosemide may be suspended or terminated. Use of furosemide can cause hypokalemia, the mechanism of action of furosemide is co-transporter inhibit $\mathrm{Na}+/ \mathrm{K}+/ 2 \mathrm{Cl}$ - that play a role in the transport of chloride through a layer of cells on Thick Assending Limb (TAL) loop of Henle.

Hypokalemia and hyperkalemia in patients with heart failure should be avoided, because they can cause disturbances in cardiac conduction, causing ventricular arrhythmias that can cause sudden death (Dursun 2006). Therefore potassium levels in heart failure patients should be maintained at normal levels of potassium and potassium levels should be monitored as well as the patient's ECG. 


\section{CONCLUSION}

Monitoring of potassium levels in heart failure patients should remains to be done to avoid hyper or hypokalium conditions. In this study there was no significant difference to the patient's potassium levels, and most patients have normal potassium levels.

\section{REFERENCES}

Braunwald, E.MD., 2013, Heart Failure, Journal American College of Cardiology Foundation, 1: 1-20

Chatterjee, N.A., Fifer, M.A., 2012. Heart Failure. In. Lilly, L.s., editor, Pathophysiology of Heart Disease, Baltimore: Lippincott William \& Wilkins, p, 216 243.

Dursun, I. and Ahin, M., 2006, Difficulties in Maintaining Potassium Homeostasis in Patiens with Heart Failure, Journal Clinical Cardiology, 29, 388-389

El-Sherif, N., Gioia Turitto, G., 2011. Electrolyte Disorders and Arrhythmogenesis Cardiology Journal. Vol. 18, No. 3, pp. 233-245

Felker, G.M., et al. 2009. Loop Diuretics in Acute Decompensated Heart Failure, Circulation Heart Failure. 2:56-62

Felker, G.M., et al. 2010. Diuretic Management in Heart Failure. Review Paper Division of Cardiology. University Medical Center: Durham NC: 568-572

Felker, G.M. et al 2011. Diuretic Strategies in Patients with Acute Decompensated Heart Failure. New England Journal of Medicine. 364:797-805.

Felker, G.M. 2012. Diuretics and Ultrafiltration in Acute Decompensated Heart Failure. Journal of the American College of Cardiology. Vol. 59: No. 24. 2145- 47

Harvey, R.A., Champe, P.C. 2009. Lippincots Illustrated Reviews: Pharmacology, Ed 4th. Lippincots Williams \& Wilkins/Wolt Kluwer Health Inc: USA. $215-230$
Huang, C.L., Kuo, E., 2011. Mechanism of Hypokalemia in Magnesium Deficiency, Journal American Society of Nephrology, 18: 2649-2652

Hunt, S.A., et al. 2009. Focused Update Incorporated: IntoTthetACC/AHA 2005 Guidelines for the Diagnosis and Management of Heart Failure in Adults A Report of the American College of Cardiology Foundation/American Heart Association Task Force on Practice Guidelines, Circulation: 119: e391- e479

Jentzer, J.C,. et al. 2010. Combination of Loop Diuretics with Thiazid-Type Diuretics in Heart Failure, Journal of the American College of Cardiology, 56: 1527-37

Katzung, B.G., 2007. Farmakologi Dasar dan Klinik: Edisi ke 10. EGC: Jakarta. 201 - 205; 240 - 243.

Kabo, P. 2010. Bagaimana Menggunakan Obat-obat Kardiovaskular secara Rasional. Balai Penerbit Fakultas Kedokteran Universitas Indonesia. 63 - 75

Lim, H., 2013 Farmakologi Kardiovaskuler, Mekanisme dan Aplikasi Klinis, Departement of Pharmacology and Moleculer Biology, Faculty of Medicine, Methodist University of Indonesia Medan, 118-135

McMurray, J.J.V. 2010. Systolic Heart Failure, Clinical Practice, The New England Journal of Medicine. 362:228-238.

McMurray, J.J.V., et. al. 2012. ESC Guidelines for the diagnosis and treatment of acute and chronic heart failure. Diagnosis and Treatment of Acute and Chronic Heart Failure Journal of the European Society of Cardiology. 33: 1787-1847

Panggabean, M.M. 2014. Gagal jantung dalam Buku Ajar Ilmu Penyakit Dalam, Jilid II, Edisi VI. InternaPublishing, Jakarta Pusat: 1132-1136.

Yancy, C.W., et al. 2013.ACCF/AHA Guideline for the Management of Heart Failure: Executive Summary A Report of the American College of Cardiology Foundation/American Heart Association Task Force on Practice Guidelines. Journal of the American College of Cardiology. Vol. 62, No. 16: 1495-1539. 